\title{
EVALUASI EFEKTIVITAS PENERAPAN SISTEM MANAJEMEN LINGKUNGAN ISO 14001 DI PABRIK BAN XYZ-JAWA BARAT (Evaluation on The Effectiveness of Implementation ISO 14001 Environmental Management System in XYZ Tyre Factory-West Java)
}

\author{
Muhammad Ryan Natasaputra ${ }^{{ }^{*}}$, Prastowo ${ }^{2}$ dan Yudi Chadirin ${ }^{2}$ \\ ${ }^{1}$ Program Studi Teknik Sipil dan Lingkungan, Fakultas Teknologi Pertanian, \\ Jalan Raya Darmaga, Bogor, Jawa Barat, 16680. \\ ${ }^{2}$ Departemen Teknik Sipil dan Lingkungan, Fakultas Teknologi Pertanian, \\ Jalan Raya Darmaga, Bogor, Jawa Barat, 16680.
}

*Penulis korespondensi. Tel: 085214020655. Email: ryan_natasaputra@yahoo.com.

Diterima: 12 Januari 2015

\begin{abstract}
Abstrak
Pabrik ban XYZ yang berlokasi di Jawa Barat merupakan salah satu industri ban yang telah memiliki komitmen untuk meningkatkan kinerja lingkungan dengan menerapkan Sistem Manajemen Lingkungan (SML) ISO 14001. Tujuan dari penelitian ini adalah untuk mengevaluasi efektivitas penerapan SML ISO 14001 berdasarkan kinerja manajemen, kinerja lingkungan, dan kesesuaian dengan sertifikasi Occupational Health and Safety Assessment Series (OHSAS) 18001. Penelitian ini dilakukan dengan dua metode, yaitu pengumpulan data primer melalui pemantauan lapang dan data sekunder melalui dokumen-dokumen yang berhubungan dengan SML serta data hasil pengukuran Aspek Lingkungan Penting (ALP). Data tersebut dievaluasi dan dibandingkan dengan SNI 19-14001-2005, program lingkungan perusahaan, serta peraturan perundangan yang berlaku agar diketahui efektivitas penerapan SML ISO 14001. Hasil penelitian menunjukkan bahwa kebijakan lingkungan telah sesuai dengan tiga komitmen utama dalam SNI 19-14001-2005. Prosedur identifikasi dan klasifikasi ALP telah dilaksanakan dengan metode penilaian terhadap empat kriteria yang dibuat oleh pihak manajemen pabrik ban. Data hasil pengukuran ALP yang dievaluasi meliputi kebisingan, debu, limbah cair industri, dan penggunaan air. Efektivitas penerapan SML ISO 14001 di pabrik ban melalui hasil penilaian kinerja manajemen sebesar 80\% dan kinerja lingkungan dari data hasil pengukuran ALP sebesar 81,3\%, secara umum membuktikan bahwa penerapan SML ISO 14001 dengan nilai pencapaian sebesar 80,7\% telah efektif dalam memenuhi tujuan dari komitmen pencegahan pencemaran, penerapan program lingkungan, dan peraturan perundangan yang berlaku. Ketidaksesuaian disebabkan oleh masalah komunikasi, kesadaran karyawan, dan kelayakan teknis. Dalam hal keselamatan dan kesehatan kerja terdapat integrasi dengan OHSAS 18001 melalui penggunaan Alat Pelindung Diri (APD) dan prosedur tanggap darurat.
\end{abstract}

Kata kunci: aspek lingkungan penting, efektivitas, kinerja lingkungan, kinerja manajemen, SML ISO 14001. 
Keywords: effectiveness, environmental performance, ISO 14001 EMS, management performance, significant environmental aspect.

\section{PENDAHULUAN}

Perkembangan sektor industri mengakibatkan dampak negatif berupa penurunan daya dukung lingkungan. Penerapan Sistem Manajemen Lingkungan (SML) ISO 14001 dilakukan untuk memenuhi peraturan dan tanggung jawab dalam mendukung perlindungan lingkungan, mencegah pencemaran, dan mendapatkan keuntungan ekonomi melalui perbaikan kinerja lingkungan secara keseluruhan (Sueb dan Keraf, 2012). SML ISO 14001 membantu manajemen industri dalam mengenal dan mengukur kinerja lingkungan terkait aspek lingkungan dari aktivitas produk serta jasa yang dihasilkan (Petrosillo dkk, 2011). Manfaat positif dalam pendekatan sistem yaitu antisipasi dampak jangka pendek maupun jangka panjang dari aspek lingkungan bagi keadaan lingkungan dan kegiatan usaha, serta hubungan dengan pemerintah dan konsumen (Adisasmito, 2014).

Kemunculan industri ban menimbulkan dampak lingkungan negatif bagi lingkungan di sekitarnya melalui aspek lingkungan berupa limbah dari proses produksi ban yang terdiri dari limbah cair, debu, limbah Bahan Berbahaya dan Beracun (B3), dan dari kegiatan mesin produksi yaitu kebisingan (Anonim, 2011). Sisa-sisa bahan kimia dalam limbah cair dan limbah B3 dapat mengurangi kualitas lingkungan hidup dengan mencemari tanah di sekitar area pabrik (Kartamihardja, 2006). Timbulan debu yang dihasilkan dapat mengganggu kesehatan pernapasan manusia dan estetika lingkungan, kemudian intensitas kebisingan yang tinggi dapat menganggu kehidupan sosial masyarakat sekitar.

Atas dasar itulah salah satu pabrik ban yang ada di Kota Bekasi menerapkan SML ISO 14001 untuk memastikan bahwa aspek lingkungan termasuk ke dalam setiap tahap dari desain dan produksi ban serta seluruh aktivitas pendukungnya sebagai proses pertimbangan program lingkungan yang bertujuan mempertahankan kinerja manajemen dalam meningkatkan kinerja lingkungan. Penerapannya juga didasari oleh perkembangan lingkungan yang strategis, tuntutan pasar internasional, dan pandangan bisnis di masa depan yang semakin ketat (Shen dan Qin, 2011). Oleh karena itu perlu dilakukan evaluasi untuk membuktikan kesesuaian dan efektivitas penerapan SML ISO 14001 dengan persyaratan SNI 1914001-2005 serta peraturan perundangan yang dijadikan acuan dan berlaku di pabrik tersebut.
Menurut Arikunto (2006) penelitian evaluasi merupakan suatu proses yang dilakukan untuk menentukan kebijakan, menimbang keuntungan penerapan program, dan melihat proses atau teknik yang digunakan dalam melakukan penilaian. Berdasarkan hal tersebut dibuatlah ruang lingkup berupa evaluasi kinerja manajemen dengan melihat pelaksanaan program, kepedulian (awareness), kompetensi, prosedur, dan rekaman dalam pengelolaan Aspek Lingkungan Penting (ALP), serta evaluasi kinerja lingkungan berdasarkan hasil yang terukur dari efektivitas penerapan ISO 14001 terhadap hasil pengukuran ALP tahun 2012-2014. Hal ini didasarkan pada pernyataan Prastowo (2009) pada hasil kajian SML di Cagar Alam dan Taman Wisata Alam Telaga Warna, bahwa efektivitas penerapan SML tidak bisa dievaluasi tanpa dokumen yang menunjukkan kinerja lingkungan khususnya ALP sebagai bukti pencapaian tujuan dan sasaran. Dalam proses pencapaiannya, Yin dan Schmeidler (2007) menyatakan bahwa memasukkan elemen-elemen kinerja manajemen dalam implementasi ISO 14001 juga dapat membantu menghasilkan peningkatan kinerja lingkungan yang lebih baik.

Sistem merupakan hal yang dinamis sehingga dapat berubah dari waktu ke waktu sesuai dengan kondisi sumber daya teknis maupun non teknis yang sedang dihadapi. Berkaitan dengan hal tersebut maka penelitian ini bertujuan untuk mengevaluasi efektivitas penerapan SML ISO 14001 terhadap kinerja manajemen sebagai faktor pendukung paradigma, awareness, dan komitmen terhadap lingkungan, kinerja lingkungan yang meliputi aplikasi kebijakan lingkungan, pengelolaan ALP, dan infrastruktur yang digunakan, serta keterkaitan dengan sertifikasi OHSAS 18001 dalam menunjang keberhasilan pengelolaan lingkungan.

\section{METODE PENELITIAN}

\section{Waktu, Lokasi dan Bahan}

Proses kegiatan penelitian dilakukan pada bulan September-Oktober 2014 di pabrik ban XYZ di provinsi Jawa Barat. Penelitian dilakukan dengan pendekatan telaah dokumen sebagai data sekunder, seperti peraturan perundang-undangan yang dijadikan acuan oleh pabrik, dokumen SNI 1914001-2005, prosedur SML ISO 14001, dokumen AMDAL, rekaman hasil audit internal, rekaman hasil audit PROPER KLH, dan dokumen kinerja lingkungan hasil pengukuran ALP. Penelitian juga 
dilakukan dengan pengumpulan data primer hasil pemantauan lapangan terhadap penerapan SML ISO 14001 serta penggunaan infrastruktur yang mendukung program pengelolaan lingkungan.

\section{Prosedur Penelitian}

Data primer didapat melalui pemantauan lapang dan wawancara dengan beberapa orang karyawan perusahaan yang bertujuan mengevaluasi pelaksanaan program pengendalian ALP secara langsung dari segi penaatan peraturan dan kelayakan infrastruktur. Pemantauan dilaksanakan dengan mengikuti ketentuan dari pembimbing lapangan dan wawancara dilakukan dengan karyawan yang ditemui selama pemantauan. Selanjutnya didapatkan hasil berupa sampel temuan-temuan ketidaksesuaian memerlukan evaluasi dan rekomendasi tindakan agar tidak terulang kembali. Data primer dianalisis dalam bentuk naratif dengan menggunakan metode kualitatif.

Data sekunder berupa hasil pengukuran ALP kebisingan, debu, limbah cair industri, dan penggunaan air dari dokumen kinerja lingkungan tahun 2012-2014 dianalisis dengan metode kuantitatif dan kualitatif dalam bentuk tabulasi. Metode pengukuran ALP dilakukan melalui kerjasama dengan pihak ketiga agar dapat dipertanggungjawabkan secara hukum. ALP kebisingan diukur dengan sound level meter dan ALP debu menggunakan high volume sampler, kedua ALP tersebut diukur dengan metode grab sampling setiap 6 bulan sekali. ALP limbah cair industri dan ALP penggunaan air diukur setiap bulan melalui pemasangan flowmeter.

Data hasil pemantauan lapangan dan pengecekan dokumen dievaluasi, khususnya penilaian faktor-faktor penentu kinerja manajemen seperti kompetensi, awareness, program, dan prosedur yang telah ditetapkan. Kinerja manajemen bertujuan meningkatkan faktor-faktor penentu kinerja lingkungan seperti pemantauan dan pengukuran ALP serta pemeliharaan sumber daya berupa. Dalam pencapaian kinerja lingkungan yang tinggi, pengelolaan ALP sangat dipengaruhi oleh dorongan manajemen lingkungan secara proaktif dan terkendali.

Indikator efektivitas digunakan dalam sebuah evaluasi untuk mengukur seberapa jauh kinerja SML dalam sebuah perusahaan. Efektivitas SML diinilai dari penerapannya melalui kinerja lingkungan yang terkait dengan ketaatan terhadap kebijakan lingkungan, pengelolaan ALP, serta tujuan dan sasaran pabrik (Prastowo 2009). Salah satu cara untuk dapat menentukan kinerja lingkungan yaitu melakukan penilaian terhadap ALP yang ada dalam ruang lingkup perusahaan. Untuk itu perlu adanya sebuah prosedur khusus dalam penilaian tersebut.

Prosedur standar identifikasi dan klasifikasi aspek lingkungan ditetapkan dalam dokumen prosedur ISO 14001 berkode INEP-431 yang didukung oleh dokumen cara penilaian aspek lingkungan dengan kode INEKS-1005 (Tabel 1) dengan lima kriteria standar penilaian. Penentuan nilai dilakukan tergantung dari kategori aspek lingkungan yang telah diklasifikasikan, dimana suatu ALP memiliki nilai total dari lima kriteria lebih dari 10.

\section{HASIL DAN PEMBAHASAN}

\section{Penerapan Kebijakan Lingkungan dan Identifikasi ALP}

Pabrik ban XYZ telah menetapkan kebijakan lingkungan sebagai dasar pengelolaan lingkungan yang disahkan oleh Direktur Teknik sebagai manajemen puncak dalam penerapan SML ISO

Tabel 1. Cara penilaian aspek lingkungan di pabrik ban.

\begin{tabular}{llc}
\hline \multicolumn{1}{c}{ Kriteria } & \multicolumn{1}{c}{ Uraian } & Nilai \\
\hline Aspek Hukum (AH) & a. Tidak terkait hukum & 1 \\
Radius Dampak (RD) & b. Terkait hukum & 3 \\
& a. Berdampak hanya di satu seksi & 1 \\
& b. Berdampak hanya di area pabrik & 2 \\
Keselamatan dan Kesehatan (KK) & c. Berdampak pada seluruh pabrik dan atau ke luar pabrik & 3 \\
& a. Tidak menimbulkan akibat bagi KK & 1 \\
Pengukuran (PR) & b. Dalam kurun waktu tertentu dapat mengganggu KK & 2 \\
& c. Berakibat langsung dan atau bagi manusia & 3 \\
Frekuensi (FR) & a. Jauh lebih kecil dari standar & 1 \\
& b. Tidak melebihi standar & 2 \\
& c. Melebihi standar & 3 \\
\hline
\end{tabular}

Sumber : Data analisis. 
14001. Isi pernyataan tersebut meliputi pencegahan pencemaran lingkungan pabrik, mematuhi peraturan perundang-undangan yang berlaku serta persyaratan lingkungan lainnya, dan melakukan perbaikan berkelanjutan. Poster kebijakan lingkungan dapat dilihat pada Gambar 1.

Pernyataan kebijakan lingkungan telah disusun oleh manajemen pabrik berdasarkan tiga komitmen utama dalam SNI 19-14001-2005. Hasil pengamatan kondisi di lapangan, terlihat bahwa poster kebijakan lingkungan telah dipasang di setiap ruangan kantor, papan SEQCD (Safety, Environment, Quality, Cost, Delivery), dan gerbang masuk utama. Setiap hari setelah senam pagi pada setiap seksi dibacakan pernyataan kebijakan lingkungan dan setiap karyawan memiliki safety handbook berisi kebijakan lingkungan. Pernyataan kebijakan lingkungan yang dibuat telah disesuaikan oleh manajemen puncak dengan kompetensi yang dimiliki karyawan pabrik.

Menurut SNI 19-14001-2005 klausul 4.2 mengenai kebijakan lingkungan, manajemen puncak harus menetapkan kebijakan lingkungan yang mencakup komitmen pencegahan pencemaran, menaati peraturan perundangundangan, dan melakukan perbaikan berkelanjutan (Anonim, 2005). Kebijakan lingkungan juga harus didokumentasikan, diterapkan, dipelihara, dikomunikasikan, dan tersedia untuk masyarakat (Anonim, 2005). Dalam hasil penelitiannya, Prastowo (2009) juga mengatakan bahwa kebijakan lingkungan harus spesifik sebagai dasar pelaksanaan yang nyata dan tidak hanya sebuah slogan, sehingga harus bisa diimplementasikan, dipelihara, dan dikomunikasikan ke semua bagian organisasi serta tersedia untuk umum. Jika dibandingkan dengan persyaratan SNI 19-140012005 dan pendapat tersebut maka isi pernyataan dan tujuan penerapan kebijakan lingkungan pabrik ini telah sesuai.

Hasil evaluasi terhadap penerapan dan sosialisasi kebijakan lingkungan melalui wawancara menunjukkan bahwa 85\% orang karyawan tidak hafal isi pernyataannya. Hasil pengecekan dokumen audit internal pada 17 seksi ditemukan bahwa di 5 seksi pelatihan ulang kebijakan lingkungan belum dilakukan dan belum ada bukti bahwa sosialisasi sudah dikomunikasikan secara menyeluruh. Kinerja manajemen dalam menerapkan tujuan kebijakan lingkungan secara efektif terhambat oleh faktor budaya kerja yang disebabkan oleh kurangnya kepedulian karyawan dalam inisiatif melakukan komunikasi dan partisipasi dalam menangani keadaan darurat. Keadaan ini sesuai dengan hasil pengamatan Rachmawati (2006) terhadap efektivitas kepemim-

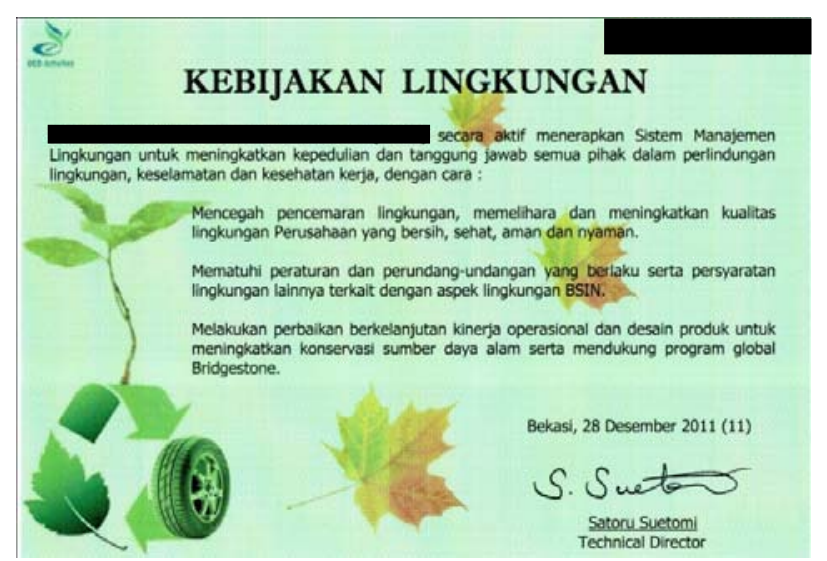

Gambar 1. Poster kebijakan lingkungan.

pinan pada pabrik tersebut yang menunjukkan bahwa karyawan cenderung bersikap pasif dan enggan menyampaikan gagasan mereka yang berhubungan dengan kemajuan perusahaan

Dalam ISO 14001 kebijakan lingkungan berperan sebagai pusat dokumen yang harus diketahui, komitmen untuk patuh pada undangundang, perbaikan berkelanjutan, dan menjadi dasar untuk menentukan tujuan dan sasaran (Emilsson dan Hjelm 2002). Jika kebijakan lingkungan terpenuhi maka kontrol terhadap klausul-klausul lainnya akan lebih mudah. Oleh karena itu diperlukan perbaikan sesuai dengan pendapat Kasman dan Isyandi (2013) bahwa komitmen manajemen dapat ditingkatkan melalui pengkomunikasian tujuan lingkungan, pemberian pelatihan yang lebih spesifik, pemberian penghargaan pada karyawan, dan lebih meningkatkan budaya partisipatif. Kinerja manajemen dalam komunikasi tujuan dan sasaran komitmen kebijakan lingkungan juga dapat ditunjang dengan pemberian sanksi yang tegas terhadap karyawan yang tidak mematuhi peraturan dan persyaratan yang ditetapkan.

Hasil identifikasi ALP ditulis dalam form identifikasi aspek lingkungan berkode SML-431SHT01, kemudian ditempel pada papan SEQCD di setiap seksi. Penetapan ALP disahkan oleh kepala seksi yang telah dilatih oleh konsultan ahli dengan pelatihan rutin identifikasi ALP yang wajib dihadiri oleh kepala seksi dan 4 orang karyawan dari tiap seksi setiap setahun sekali. Hasil identifikasi beredar di intranet dalam bentuk dokumen rekaman klasifikasi aspek lingkungan berkode SML-431SHT02. Prosedur ini dilakukan berdasarkan SNI 19-14001-2005 pada klausul 4.3.1 mengenai aspek lingkungan, klausul 4.4.4 mengenai dokumentasi, dan klausul 4.4.5 mengenai pengendalian dokumen. Jika dibandingkan maka prosedur penetapan ALP telah sesuai dengan persyaratan SNI 19-14001- 
2005 pada klausul 4.3.1 dan 4.4.4, namun tidak dengan klausul 4.4.5.

Hasil evaluasi terhadap dokumen audit internal pada 17 seksi menunjukkan bukti bahwa pada 14 seksi belum dilakukan kegiatan sosialisasi, pelatihan dan pembaharuan dokumen identifikasi dan klasifikasi ALP. Ketidaksesuaian yang ditemukan antara pelaksanaan di lapangan dengan persyaratan SNI 19-14001-2005 klausul 4.4.5 disebabkan oleh kurangnya kepedulian karyawan dan pengawasan manajemen pabrik. Dalam penelitian Hidayat (2004), aspek pelaksanaan berarti harus menerapkan program yang telah disusun pada aspek perencanaan sehingga memerlukan tanggung jawab dari prosedur untuk melaksanakan program demi tercapainya tujuan dan sasaran. Diperlukan upaya pengawasan yang lebih ketat oleh kepala seksi dalam pembaharuan dokumen, salah satunya pembuatan dokumen hardcopy hasil identifikasi dan klasifikasi aspek lingkungan.

\section{Penyajian Gambar}

Terdapat beberapa Aspek Lingkungan Penting (ALP) yang berdampak penting di pabrik ban tersebut, antara lain kebisingan, debu, limbah cair industri, dan penggunaan air. Pihak manajemen telah membuat beberapa program lingkungan dengan tujuan pengurangan tingkat penyebaran dampak dan sasaran nilai pengukuran dampak sesuai dengan baku mutu peraturan yang berlaku. Program lingkungan yang telah ditetapkan terlihat dalam Tabel 2.

Kinerja manajemen dalam pelaksanaan program-program tersebut terlihat dari pembagian peran dan tanggung jawab kepada setiap karyawan menurut kompetensinya masing-masing. Dalam melaksanakan peran dan tanggung jawab kerja terutama pengelolaan ALP para karyawan telah diberikan pelatihan yang dijadwalkan minimal setahun sekali dalam upaya peningkatan kompetensi serta kepeduliannya. Para karyawan juga diberikan prosedur penggunaan Alat Pelindung Diri (APD) dalam melaksanakan pekerjaan dan penanganan ALP terutama di area-area yang berbahaya. Prosedur-prosedur yang ditetapkan sebagai keberlanjutan dari program lingkungan antara lain pemasangan tanda bahaya kebisingan, pengemasan debu ke kantong plastik, penanganan kontaminasi limbah cair, dan pemeliharaan infrastruktur WTP. Prosedur yang dilaksanakan juga termasuk ke dalam persyaratan dalam sertifikasi OHSAS 18001.

Sumber daya yang disediakan dalam penanganan ALP limbah cair industri berupa infrastruktur WWTP terdiri dari pool neutralizing berkapasitas $160 \mathrm{~m}^{3}$ dengan teknologi air blower, pool separator air dan minyak dengan teknologi sensor nilai $\mathrm{pH}$ dan return pump, serta end separator dengan teknologi sensor nilai $\mathrm{pH}$ dan TDS sesuai kriteria sasaran milik pabrik $(\mathrm{pH}$ 6,58,5 dan TDS <3500 ppm) yang dibuat lebih ketat daripada standar baku mutu menurut Keputusan Gubernur Jawa Barat Nomor 6 Tahun 1999 yaitu pH 6,0-9,0 dan TDS 4000 ppm. Terdapat pula WTP untuk ALP penggunaan air dengan kapasitas olah $80 \mathrm{~m}^{3} / \mathrm{jam}$ dan dust collector untuk ALP debu dengan daya penyedotan inlet $1 \mathrm{~m} /$ det.

Kinerja lingkungan terlihat dari hasil kegiatan pemantauan dan pengukuran ALP yang dilakukan dalam rangka memenuhi standar baku mutu dari peraturan perundangan serta persyaratan yang dijadikan acuan. Hasil dan evaluasi terhadap kinerja lingkungan perusahaan menentukan seberapa jauh efektivitas penerapan SML ISO 14001 terhadap pelaksanaan komitmen manajemen puncak yang

Tabel 2. Program lingkungan di pabrik ban.

\begin{tabular}{ll}
\hline ALP & Program \\
\hline Kebisingan & Pengukuran dua kali setahun \\
& Pemeliharaan tanaman penyerap kebisingan \\
& Perawatan mesin-mesin produksi \\
& Pemasangan dinding penyekat kedap suara dan silencer pada bagian exhaust mesin \\
& Pengontrolan checksheet kondisi dust collector \\
& Pemantauan dan pengukuran debu dua kali setahun \\
& Pemeliharaan tanaman penyerap debu \\
& Pengoperasian mobil penyiram jalan \\
& Pengoperasian Waste Water Treatment Plant (WWTP) \\
& Pengukuran 33 parameter limbah cair setiap bulan \\
& Pengukuran debit pembuangan limbah cair setiap hari \\
& Pengecekan flood control \\
& Penempelan stiker hemat air \\
& Mematikan penggunaan air pada jam-jam tertentu \\
& Pengecekan flowmeter dan pipa penyalur air Water Treatment Plant (WTP) \\
& Mendaur ulang air limbah dari kegiatan domestik \\
\hline
\end{tabular}


tercantum dalam kebijakan lingkungan. Hasil kinerja lingkungan terhadap pemantauan dan pengukuran ALP kebisingan di lingkungan kerja dari tahun 2012-2014 terdapat pada Gambar 2.

Hasil pengukuran di lima titik sampel area produksi dari tahun 2012-2014, tingkat kebisingan tertinggi terdapat di Utility pada bulan November 2013 sebesar 88,6 dBA. Penilaian tingkat kebisingan mengacu pada Peraturan Menteri Tenaga Kerja Nomor 13 Tahun 2011 dengan baku mutu yang ditetapkan sebesar 85 dBA. Jika membandingkan hasil dan regulasi maka masih terdapat beberapa area yang melebihi baku mutu, namun pada pengukuran terakhir kebisingan tertinggi hanya terdapat pada seksi Calendering. Gambar 3 menunjukkan kinerja lingkungan hasil kegiatan pengukuran tingkat kebisingan pemukiman penduduk dari tahun 2012-2014.

Kebisingan tertinggi sebesar 65 dBA terdapat pada bulan Oktober 2012 di perumahan pabrik ban Blok A. Mengacu pada baku mutu Keputusan Menteri Lingkungan Hidup Nomor 48 Tahun 1996 untuk kawasan industri sebesar $70 \mathrm{dBA}$, maka hasil masih berada di bawah baku mutu yang ditetapkan. Berdasarkan hasil maka dapat dinilai pelaksanaan program pemeliharaan tanaman penyerap kebisingan sudah tepat sasaran. Kinerja lingkungan pada kegiatan pengukuran debu lingkungan kerja terdapat pada Tabel 3. Pengukuran dilakukan dengan menggunakan filter fiber glass microfiber dan high volume air sampler (HVAS) dan dianalisis secara gravimetri. Pada Maret 2012 pihak manajemen tidak melakukan pengukuran pada dua titik sehingga tidak ada datanya.

Terlihat bahwa nilai debu tertinggi terdapat pada bulan Oktober 2012 di area Tube sebesar $8,6072 \mathrm{mg} / \mathrm{m}^{3}$, namun masih di bawah baku mutu Peraturan Menteri Tenaga Kerja Nomor 13 Tahun 2011 sebesar $10 \mathrm{mg} / \mathrm{m}^{3}$. Hasil pemantauan menunjukkan penempatan dust collector efektif dalam mengendalikan timbulan debu. Kinerja lingkungan pengukuran debu udara ambien ditunjukkan dalam Tabel 4.

Diketahui nilai tertinggi terdapat pada lokasi depan TWH-B pada bulan November 2013 sebesar $16,1031 \mathrm{mg} / \mathrm{m}^{3}$ dan sudah melebihi nilai baku mutu Peraturan Pemerintah Nomor 41 Tahun 1999 sebesar $0,23 \mathrm{mg} / \mathrm{m}^{3}$. Hasil tersebut dipengaruhi oleh keadaan iklim dan menurut pihak manajemen juga dipengaruhi oleh kebocoran cerobong asap milik pabrik lain, sehingga pada keadaan normal pelaksanaan program pemeliharaan tanaman dan penyiraman jalan sudah efektif dalam mengurangi timbulan debu.

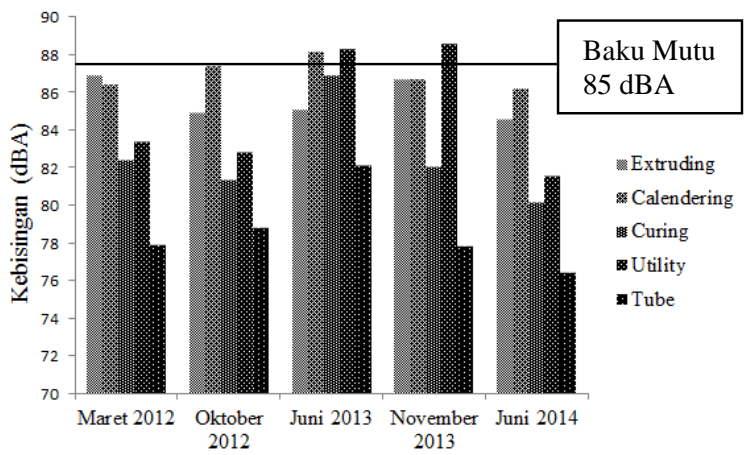

Gambar 2. Grafik kebisingan lingkungan kerja.

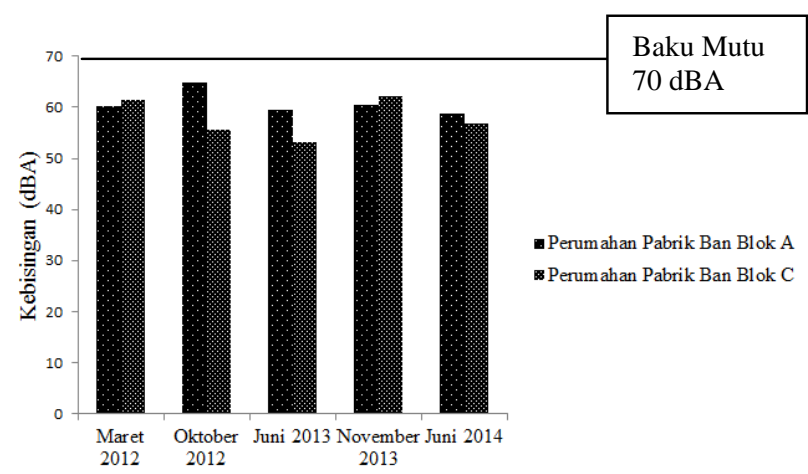

Gambar 3. Grafik kebisingan pemukiman penduduk.

Tabel 3. Hasil pengukuran debu lingkungan kerja.

\begin{tabular}{lccccc}
\hline \multirow{2}{*}{ Titik pengukuran } & \multicolumn{5}{c}{ Debu (mg/m ${ }^{3}$. } \\
\cline { 2 - 6 } & Maret 2012 & Oktober 2012 & Juni 2013 & November 2013 & Juni 2014 \\
\hline Tube & 1,4637 & 8,6072 & 0,0090 & 0,3211 & 0,0008 \\
Tire Curing & 0,0336 & 0,4656 & 0,0011 & 0,6443 & 0,0002 \\
Blending Chemical & - & 0,5746 & 0,0010 & 0,4885 & 0,0013 \\
Carbon Banburry & - & 1,3522 & 0,0003 & 1,1323 & 0,0007 \\
\hline Baku mutu debu & $10 \mathrm{mg} / \mathrm{m}^{3}(8 \mathrm{jam})$ & & & \\
\hline
\end{tabular}

Tabel 4. Hasil pengukuran debu udara ambien.

\begin{tabular}{lccccc}
\hline \multirow{2}{*}{ Titik pengukuran } & \multicolumn{5}{c}{ Debu $\left(\mathrm{mg} / \mathrm{m}^{3}\right)$} \\
\cline { 2 - 6 } & Maret 2012 & Oktober 2012 & Juni 2013 & November 2013 & Juni 2014 \\
\hline Depan koperasi & 0,0823 & 14,1066 & 0,0003 & 8,4281 & 0,0001 \\
Depan LLK & 0,0511 & 13,9109 & 0,0002 & 3,8279 & 0,0003 \\
Depan TWH-B & 0,1158 & 0,023 & 0,0002 & 16,1031 & 0,0002 \\
\hline Baku mutu debu & $0,23 \mathrm{mg} / \mathrm{m}^{3}(24 \mathrm{jam})$ & & & \\
\hline
\end{tabular}


Kinerja lingkungan ALP limbah cair industri ditunjukkan oleh pengukuran nilai $\mathrm{pH}$ (Gambar 4) dan TDS (Gambar 5) pada periode Januari-Agustus tahun 2014. Dapat dilihat bahwa nilai pH tertinggi terdapat pada bulan Januari yaitu 7,97 dan nilai TDS tertinggi terdapat pada bulan Juni yakni sebesar 2572 ppm. Hasil tersebut masih di bawah baku mutu yang ditetapkan menurut Keputusan Gubernur Jawa Barat Nomor 6 Tahun 1999 dengan kisaran nilai $\mathrm{pH}$ antara 6,0-9,0 dan TDS sebesar 4000 ppm dan juga telah memenuhi kriteria sasaran pabrik ban.

Penilaian kinerja lingkungan selanjutnya dinilai dari jumlah pemakaian air setiap bulan pada tahun 2014 yang ditunjukkan dalam Tabel 5. Izin pemakaian air sungai berasal dari Surat Izin Pengambilan dan Pemanfaatan Air (SIPPA) dengan batas pengambilan air melalui WTP sebesar 47.952 $\mathrm{m}^{3}$ /bulan. Jika melihat hasil pengukuran maka SIPPA telah dipenuhi dengan baik karena tidak ada jumlah pemakaian air yang melebihi izin pemakaian. Hasil pemantauan diketahui batas berlakunya SIPPA telah berakhir pada tanggal 13 Desember 2013 dan masih dalam proses perpanjangan meski sudah diajukan sebelum izin berakhir. Penghentian sementara pada penggunaan air sungai tidak bisa dilakukan karena kualitas air tanah untuk air baku kurang bisa diandalkan. Kesalahan ini tidak sepenuhnya berada di tangan pengelola pabrik karena adanya hal-hal seperti kondisi sosial yang lemah di masyarakat dan penanganan mengenai perijinan yang lambat di pemerintahan. Solusi dari masalah tersebut perusahaan telah mengurus surat izin sementara agar tidak terkena tindak pidana pengambilan air secara ilegal.

Sejak tahun 2011 pemakaian air tanah di pabrik ban ini hanya digunakan sebagai back up dari operasional WTP sehari-harinya, sehingga dari 9 sumur bor yang telah dilengkapi Surat Izin Pengambilan Air Tanah (SIPA) digunakan hanya 1 yaitu sumur bor nomor 3. Operasional sumur bor nomor 3 ini seringkali digunakan apabila pasokan air dari WTP mengalami kendala atau kurang

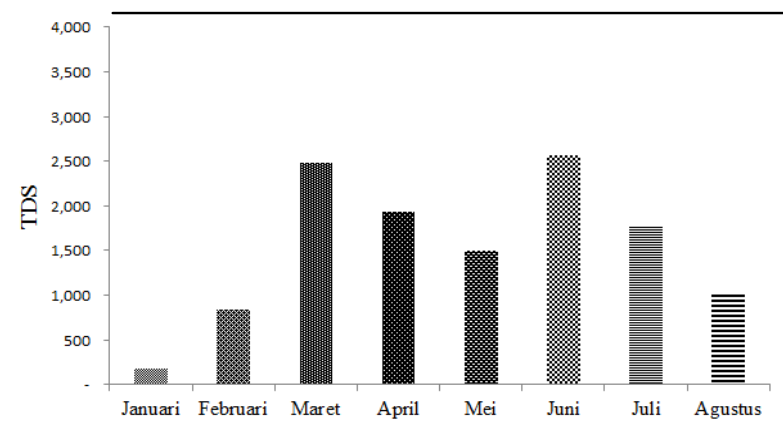

Gambar 5. Grafik hasil pengukuran parameter TDS. mencukupi kebutuhan. Debit pemakaian sumur bor nomor 3 pada tahun 2014 ditunjukkan oleh Gambar 6.

Pemakaian sumur bor nomor 3 tertinggi terdapat pada bulan Januari sebesar $6277 \mathrm{~m}^{3}$. Jika hasil dibandingkan dengan batas pengambilan air menurut Surat Izin Pengambilan Air Bawah Tanah (SIPA) sebesar $4140 \mathrm{~m}^{3} /$ bulan, maka pemakaian telah melebihi batas yang diizinkan. Hal ini disebabkan oleh kerusakan flow meter pada intake sumur bor nomor 3 karena pengendalian operasional, perawatan yang kurang ketat, dan pelaporan kondisi abnormal pada infrastruktur yang lamban, sehingga perusahaan perlu meningkatkan kepedulian dari karyawan pelaksana melalui program pelatihan.

Secara keseluruhan dapat dikatakan bahwa efektivitas penerapan SML ISO 14001 dalam mendukung kinerja lingkungan sudah efektif. Hal ini juga didukung dengan adanya program keselamatan dan kesehatan kerja yang terdapat dalam OHSAS 18001 dan tersedianya infratruktur dalam penanganan ALP. Meski demikian, hasil observasi terhadap kepedulian karyawan menemukan bahwa tidak semua karyawan menggunakan APD walau telah disyaratkan juga dalam OHSAS 18001. Pengawasan manajemen yang kurang efektif menjadi penyebab berkurangnya kepedulian dari karyawan yang pada

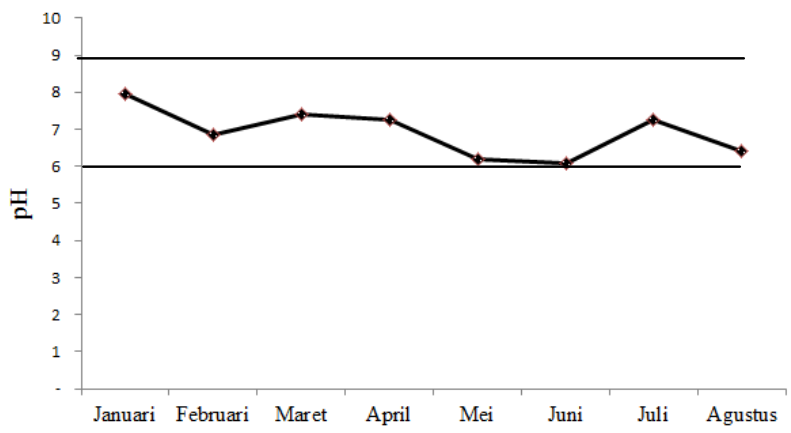

Gambar 4. Grafik hasil pengukuran parameter pH.

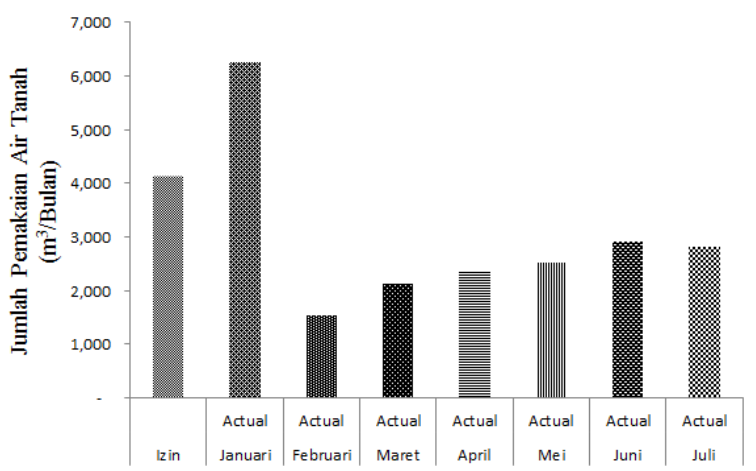

Gambar 6. Grafik jumlah debit sumur bor nomor 3. 
Tabel 5. Jumlah pemakaian air aktual per bulan $\left(\mathrm{m}^{3}\right)$.

\begin{tabular}{cccccccc}
\hline Sumber & Januari & Februari & Maret & April & Mei & Juni & Juli \\
\hline WTP Intake & 33.436 & 40.584 & 35.108 & 42.141 & 38.357 & 38.366 & 39.850 \\
WTP Outlet & 36.088 & 39.321 & 34.453 & 40.100 & 36.363 & 36.412 & 38.082 \\
\hline
\end{tabular}

Sumber : Data analisis.

dasarnya memiliki tingkat inisiatif dan partisipatif yang masih rendah.

Beberapa infrastruktur juga memerlukan perhatian karena kondisi yang kurang terawat, antara lain dust collector yang terkadang tidak sesuai dengan persyaratan teknis laju penyedotan inlet sebesar $1 \mathrm{~m} / \mathrm{s}$, WWTP dengan kondisi pipa dan tangki banyak yang sudah berkarat, dan sistem drainase air hujan yang kadang masih tercampur oleh limbah cair. Hasil penilaian PROPER KLH juga masih mendapatkan status biru yang berarti perusahaan baru bisa memenuhi semua pengelolaan lingkungan sesuai dengan baku mutu yang ditetapkan. Pada kenyataannya baku mutu yang ditetapkan oleh peraturan resmi pemerintah tidak selalu bisa dipenuhi pihak manajemen di setiap pengeloaan ALP yang dilakukan.

Rekomendasi yang dapat diambil dan diterapkan pada perusahaan yaitu melakukan perbaikan melalui komunikasi, pengawasan, dan self checking system bagi karyawan, serta pemeliharaan kondisi operasional infrastruktur pendukung dalam pengelolaan lingkungan. Beberapa kondisi yang telah efektif dan sesuai dalam pemenuhan ISO SML 14001 perlu dipertahankan dan ditingkatkan melalui tinjauan manajemen secara berkala sehingga tercapai perbaikan kinerja lingkungan yang berkelanjutan.

\section{KESIMPULAN}

Kinerja manajemen dalam pelaksanaan program lingkungan SML ISO 14001 melalui pendekatan paradigma, kepedulian dan komitmen dinilai baru $80 \%$ efektif terhadap prosedur pengelolaan lingkungan. Pihak manajemen telah membuat kebijakan lingkungan sesuai dengan tiga komitmen utama dalam SNI 19-14001-2005, namun dalam mencapai kesesuaian masih terhambat oleh beberapa masalah seperti prosedur pengendalian dokumen identifikasi dan klasifikasi ALP, sosialisasi kebijakan lingkungan, faktor budaya kerja, dan kepedulian karyawan. Kinerja lingkungan dalam pengendalian ALP dinilai telah efektif dalam mencegah pencemaran dan upaya pemenuhan regulasi karena telah mencapai 81,3\%. Secara umum efektivitas penerapan SML ISO 14001 di pabrik ban melalui penilaian kinerja manajemen dan kinerja lingkungan telah mencapai $80.7 \%$. Kesesuaian yang terdapat antara penerapan
SML ISO 14001 dengan persyaratan dalam OHSAS 18001 terlihat dari pemakaian APD oleh karyawan, adanya tindakan tanggap darutat, ketaatan terhadap prosedur, dan pengendalian operasional dalam pengelolaan lingkungan.

\section{UCAPAN TERIMAKASIH}

Terima kasih penulis ucapkan kepada PT BTI Bekasi plant atas kesempatan yang telah diberikan kepada penulis dalam melaksanakan penelitian dan pengumpulan data dalam melakukan evaluasi terhadap penerapan Sistem Manajemen Lingkungan ISO 14001.

\section{DAFTAR PUSTAKA}

Adisasmito, W., 2014. Sistem Manajemen Lingkungan Rumah Sakit. Rajawali Pers, Jakarta.

Anonim, 2005. SNI 19-14001-2005. Sistem Manajemen Lingkungan - Persyaratan dan Panduan Penggunaan, Jakarta.

Anonim, 2011. Studi Kelayakan Pembangunan Pabrik Ban di Sumatera Barat. Laporan Kerjasama Universitas Andalas dan BKPM Sumatera Barat, Padang.

Arikunto S., 2006. Prosedur Penelitian: Suatu Pendekatan Praktek. PT Rineka Cipta, Jakarta.

Emilsson, S., dan Hjelm, O., 2002. Implementation of Standardised Environmental Management Systems in Swedish Local Authorities: Reasons, Expectations, and Some Outcomes. Environmental Science and Policy, 5: 443-448.

Hidayat, A.C., 2004. Evaluasi Pelaksanaan Sistem Manajemen Lingkungan ISO 14001 pada PT Pupuk Kalimantan Timur. Tesis. Universitas Diponegoro, Semarang.

Kartamihardja, L., 2006. Mempelajari Sistem Produksi pada PT Elang Perdana Tyre Industri. Skripsi. Institut Pertanian Bogor, Bogor.

Kasman, dan Isyandi, B., 2013. Faktor Manajemen Sumber Daya Manusia (MSDM) Dalam Penerapan Sistim Manajemen Lingkungan (SML) ISO 14001 di PT Riau Andalan Pulp and Paper. Jurnal Ilmu Lingkungan, 7(2):253262.

Petrosillo, I., De Marco, A., Botta, S., dan Comoglio, C., 2011. EMAS in Local 
Authorities: Sustainable Indicators in Adopting Environmental Management Systems. Ecological Indicators, 13:263-274.

Prastowo., 2009. Review on Environmental Management System of CA and TWA Telaga Warna. Working Paper No. 12. Center for Environmental Research IPB, Bogor.

Rachmawati, B., 2006. Analisis Faktor-Faktor yang Mempengaruhi Efektivitas Kepemimpinan dalam Meningkatkan Produktivitas Karyawan PT. Bridgestone Tire Indonesia. Skripsi. Institut Pertanian Bogor, Bogor.

Shen, J.Y., dan Qin, X.D., 2011. What Determines Chinese Firms Decision on Implementing Voluntary Environmental Schemes?. Journal of Service Science and Management, 4(3):380390.

Sueb, M., dan Keraf, M.N.I., 2012. Relasi Sistem Manajemen Lingkungan ISO 14001 dan Kinerja Keuangan. Jurnal Dinamika Manajemen, 3(1):69-75.

Yin, H., dan Schmeidler, P.J., 2007. Does ISO 14001 Certification Enhance Environmental Performance? Conditions under which Environmental Performance Improvement Occurs. Wharton Risk Center Working Paper \# 07-07. Risk Management and Decision Processes Center The Wharton School University of Pennsylvania, Philadelphia. 